\title{
Big Data Meets the Shulhan Arukh
}

\author{
Michael Pitkowsky
}

\section{Earlier Discussions of the Sources Used in the Shulhan Arukh ${ }^{1}$}

Soon after its publication, commentators began to pore over almost every statement in Yosef Karo's Shulhan Arukh. Some commentators wanted to simply elucidate Karo's sometimes laconic language, desiring to help readers understand statements whose meaning or intention weren't clear. Others felt the need to further expand upon Karo's text, adding layer upon layer of interpretation. This multi-layered approach of the commentaries on the Shulhan Arukh was even cited by Abraham Zevi Hirsch Eisenstadt in his Pithei Teshuvah in order to justify the reliance on the Shulhan Arukh for halakhic decision-making. In response to the criticism of those who used the Shulhan Arukh as the sole source for halakhic decision-making voiced by the Maharsha, Samuel Edels, ${ }^{2}$ Eisenstadt wrote that

It is possible that [Maharsha adopted his position because] in Maharsha's time no glosses had yet been written to the Shulhan Arukh. Nowadays, however, since Taz, Shakh, Magen Avraham, and other later commentaries have been written and the reason for each law is explained alongside it [i.e. alongside the law itself], reliance on the Shulhan Arukh and the later commentaries is appropriate. ${ }^{3}$

Thus we see that the commentaries that were written on the Shulhan Arukh became almost inseparable from the text itself.

I would like to return to the very text of the Shulhan Arukh that has at times been almost superseded by the many commentaries that have been written on

1 I would like to thank this volume's honoree, Rabbi Joel Roth, for all that he has taught me about halakhah and halakhic literature. Through his many public talks and lectures, writings, and personal conversations Rabbi Roth has helped shape my understanding of what it means to be a Jew who tries to live their life according to the halakhah.

2 See Maharsha, Hiddushei Aggadot, Soțah 22a, s.v. Yere et ha-shem beni. Cited in Menachem Elon, Jewish Law: History, Sources, Principles, trans. B. Auerbach and M. Sykes (Philadelphia: Jewish Publication Society, 1994), 1422.

3 Pithei Teshuvah, Shulhan Arukh, YD par. 242, subpar. 8. Cited in Elon, ibid. 
it. ${ }^{4}$ Specifically, I would like to examine the sources that Karo used in compiling the Shulhan Arukh by utilizing tools of data analysis that are based upon examining collections of data, asking specific questions about this data, quantifying the answers to those questions, and using these answers as the foundation for further analysis of the material.

Previous scholars, both academic and traditional, have already asked similar questions about the sources that Karo used in composing the Shulhan Arukh and any possible modifications or editing that Karo may have applied to these texts. Alyssa Gray, in her insightful article that included a literary analysis of the laws of charity in the Shulhan Arukh, showed both Karo's reliance on Jacob b. Asher's Tur and also the freedom that he sometimes took with the sources from the Tur. ${ }^{5}$

SA's literary dependency on Tur has been long-known, as well as its tendency to make changes to Ṭu. By thinking about SA as not simply a "law code," "restatement," or "collection of rulings," but as a work of legal and literary interpretation in which a gifted scholar systematized his interpretations of and additions to his received legal heritage, the door is opened to searching out the "latent structures of thought" in the work-in this case pertaining to poverty, the poor, and the Jewish communities of which they are a part. Moreover, by noting the differences between the laws of poverty and charity that SA inherited and what it bequeathed, this study is able to show aspects of sA's distinctive contribution to that body of law, including its reintroduction of topics (as James Boyd White and J.M. Balkin understand the term) that would thenceforth be part of the canon of poverty and charity topics for study and application. To paraphrase James Boyd White, sA may be understood as "attempting to establish a conversation of a certain kind," and as "establishing a set of topics, a set of terms in which those topics can be discussed, and some general directions as to the process of thought and argument" by which its laws are to be applied. ${ }^{6}$

Gray understood how an examination of Karo's literary sources and any editing that these sources may have undergone are essential to helping us understand the nature and goals of the Shulhan Arukh.

4 For a bibliography of scholarly literature on the Shulhan Arukh see Alyssa Gray, "Poverty and Community in R. Joseph Karo's Shulhan Arukh: 'Law and Literature' and Halakhic History," Diné Israel 29 (2013): $57^{*}-89^{*}$, esp. at nn. 1-5.

5 Gray, "Poverty and Community."

6 Gray, "Poverty and Community," 88*. 
Among traditional scholars, in the seventeenth century Hayyim Benvenisti recognized Karo's reliance on the Rambam's Mishneh Torah, writing

That which R. Yosef Karo decided in his "short work" [i.e. the Shulhan Arukh], is not decisive enough for us to rely upon it, since it is known that this book is entirely based upon the reasoning of the Rambam. ${ }^{7}$

More recently Yitzhak Yosef has formulated a good summary of Karo's reliance on previous literary sources. ${ }^{8}$

And that which we have found regarding a number of contradictions in the words of Maran [i.e. Karo] in the Shulhan Arukh, the essence of the matter is that since the method of Maran the Shulhan Arukh is to rely upon the language of the poseqim [halakhic decisors], and he doesn't use his own words, sometimes he copies the language of the Rambam, and he doesn't intend to [i.e. agree with] all of the words, and sometimes he copies the language of the Rosh (Rabbeinu Asher) or the Tur, every case must be examined individually. ${ }^{9}$

We have seen that both critical and traditional scholars have both exhibited an awareness of the literary dimensions of the Shulhan Arukh and have offered numerous observations regarding the sources that Karo used when composing the Shulhan Arukh. The two dominant sources used by Karo that scholars have identified were the Rambam's Mishneh Torah and Yaakov ben Asher's Tur.

\section{A Data-Based Analysis of the Sources Found in the Shulhan Arukh}

I will now present the preliminary results of an analysis of the first 25 simanim (chapters) of the Orah Hayyim (OH) section of the Shulhan Arukh that includes both an attempt to identify the sources that Karo used in composing the Shulhan Arukh and also a discussion of some of the editorial activity undertaken

7 Hayyim Benvenisti, Shayarei Knesset ha-Gedolah, оң 495:5. For other sources that stated something similar see Yitzhak Ze'ev Kahana, Mehkarim be-Sifrut ha-Teshuvot (Jerusalem: Mossad Harav Kook, 1973), 69-70.

8 Yosef was addressing the phenomenon of contradictions that are found between different statements in the Shulhan Arukh. This question has also been treated by Eliav Shochetman, "AlHa-Setirot be-Shulhan Arukhve-AlMahuto ShelHa-Hibbur U-Mațarotav," Asufot: Sefer Shanah le-Mada'ei ha-Yahadut 3 (1989-199o): 323-329.

9 Yitzhak Yosef, Ein Yitzhak (Jerusalem: Ei”sh Pituhim, 2009), 3:62. 
TABLE 9.1 Major sources of citations in the Shul-

han Arukh sections under review

Source Number of times

\begin{tabular}{lr} 
Beit Yosef & 125 \\
Tur & 87 \\
Rambam & 22 \\
Rosh on the Talmud & 25 \\
Karo's own words & 25 \\
Rashi on the Talmud & 18 \\
Babylonian Talmud & 16 \\
Nimukei Yosef & 13 \\
Tosafot & 12 \\
Orhot Hayyim & 11 \\
Yitzhak Abuhav & 11 \\
Zohar & 10 \\
\hline
\end{tabular}

by Karo in his writing of the Shulhan Arukh. These results are very preliminary, based upon only the first 25 simanim of the Shulhan Arukh, and it is very possible that they will have to be modified after further research.

In the first 25 simanim of the Shulhan Arukh there are 170 se'ifim (paragraphs). ${ }^{10}$ The topics covered in these simanim are: hanhagat adam ba-boker (morning behavior by a person); levishat begadim (wearing clothing); hanhagat beit ha-kisei (bathroom behavior); netilat yadayim (washing one's hands); kavvanat ha-berakhot (proper intention for blessings); birkat asher yatzar ve'elohai neshama (the blessings of asheryatzar and elohai neshama); Tzitzit (ritual fringes); Talit (four cornered garments); Tefillin (phylacteries). ${ }^{11}$ I will begin by presenting some data points regarding the sources that Karo brought and then illustrate some of these with examples from the Shulhan Arukh itself.

In these 25 simanim Karo quoted from 47 different sources, this is in addition to the instances in which Karo formulated a statement entirely of his own words. A breakdown of the most frequently cited sources can be found in table 9.1.

10 Some of the se'ifim include more than one halakhah but my total count is of simanim and se'ifim and not halakhot [laws].

11 There are more halakhot related to Tefillin in subsequent simanim that I have not included. I have also not listed all of the sub-categories of the laws of Tzitzit. 
The sources cited fewer than ten times can be found in table 9.2.

I will now analyze in more detail the data found in the above tables. First, it should be pointed out that in these 25 chapters Karo used material from over three-dozen different sources. ${ }^{12}$ I would first like to go into further detail regarding the sources from the Tur and the Rambam. Table 9.3 shows the number of sources from the Rambam quoted in the Shulhan Arukh, how many were quoted verbatim, and how many of these were also quoted in the Tur..$^{13}$

From table 9.3 it is possible to see that of the 22 sources brought from the Rambam in these simanim of the Shulhan Arukh, six of those were brought verbatim without any changes. Of these 22, seven were also brought in the Tur. We can therefore say that in the simanim examined, the majority of the sources brought from the Rambam underwent some type of editing and a little less than a third of the sources brought from the Rambam were also quoted by the Tur.

Regarding the sources quoted from the Tur, of these 87 sources 16 were quoted verbatim, meaning that in the simanim that I examined of the sources that Karo brought from the Tur, $18 \%$ of them were quoted verbatim while he edited $82 \%$ of them. Below we will go into further detail and bring examples of the types of editing done to sources from both the Rambam and the Tur.

By far the largest number of sources found in these simanim of the Shulhan Arukh come from Karo's commentary on the Tur, the Beit Yosef. Of the 125 instances in which a source from the Beit Yosef is brought in the Shulhan Arukh, 25 of them are either verbatim or near verbatim statements that Karo himself wrote in the Beit Yosef, while the other 100 sources are almost without exception from other Rishonim (medieval rabbinic authorities) who are listed in Tables 9.1 and 9.2. It should be noted that, with very few exceptions, sources from the Rambam that are found in the Shulhan Arukh were either first brought in the Tur or the Beit Yosef.

12 In a preliminary examination of the first 100 chapters (simanim) of the Shulhan Arukh I have identified material from approximately 75 different sources. For a discussion of the books that Karo had at his disposal see Yehudah Lavi, "Otzar ha-Sefarim shel ha-Beit Yosef," Ha-Ma'ayan 34, no. 2 (Tevet, 5744): 21-42; Tirza Kelman, "Ketuvot be-Ot Barzel ve-Oferet biDefus: Mahapeikhat ha-Defus ve-Yetzirat ha-Hibbur Beit Yosef," Pe'Amim 148 (2016): 9-26.

13 I would like to thank Tirza Kelman for stressing to me the importance of distinguishing between material that Karo has brought in the Shulhan Arukh from the Mishneh Torah but was not also brought by Yaakov ben Asher in the Tur and material from the Mishneh Torah that was also brought in the Tur. 
TABLE 9.2 Minor sources of citations cited in the Shulhan Arukh sections under review

Source

Number of times

Agur

9

Responsa of the Rashba 8

Hagahot Maimoniyot 8

Abudaraham $\quad 7$

Mordechai 7

Semag 6

Semak 5

Ittur $\quad 5$

Kol Bo 5

Rabbeinu Yonah 4

Rabbeinu Yeruham 4

Terumat ha-Deshen 4

Responsa of the Maharik 3

Responsa of the Rosh 3

Responsa attributed to Ramban 2

Rokeah 2

Responsa of the Maharil 2

Kaftor va-Ferah 2

Ran 2

Responsa of the Ribash 2

Yaakov ibn Habib 1

Sefer ha-Batim 1

Menachem Recanati 1

Midrash Tanhuma 1

Responsa R"I Migash 1

Tashbetz 1

Shibbolei ha-Leket 1

Ra"ah (Aharon ha-Levi) 1

Maggid Mishneh 1

Tosefta 1

Jerusalem Talmud 1

Sheiltot 1 
TABLE 9.3 Citations of Maimonides in the Shulhan Arukh sec-

tions under review

Sources from the Rambam

Sources from the Rambam quoted verbatim

Sources from the Rambam also in the Tur
22

$6(27 \%)$

$7(31 \%)$

The above figures show that the sources for the simanim in the Shulhan Arukh that I examined come from the following sources: the Tur; the Rambam; sources in the Beit Yosef, whether they are from the Talmud, the Rambam, other Rishonim, or the words of Karo himself.

\section{Verbatim Quotations in the Shulhan Arukh from the Tur and the Rambam $^{14}$}

I would now like to bring some specific examples of the types of sources that are found in the Shulhan Arukh and some characteristics of the editing that they sometimes underwent. ${ }^{15}$ The first type of sources that I want to bring are verbatim quotations from either the Tur or the Mishneh Torah that were then brought in the Shulhan Arukh.

רמב"ם הלכות בית הבחירה ז:ט

שלהן ערוך אירח היים ג:

המטיל מים מן הצופים ולפנים ישב ופניו כלפי

הקדש או יסלק הקדש לצדדין.
המטיל מים מן הצופים ולפנים ישב ופניו כלפי

הקודש או יסלק הקודש לצדדין.

14 The texts of the Mishneh Torah are from the Rambam Meduyak (Maaleh Adumim, 2008), and translations from https://www.chabad.org/library/article_cdo/aid/682956/jewish/ Mishneh-Torah.htm.

Texts from the Tur and the Shulhan Arukh are from Tur ha-Shalem Shirat Devorah veShulhan Arukh ha-Bahir (Jerusalem, 2016). Early printed editions of the Shulhan Arukh have also been used. Translations from the Tur and the Shulhan Arukh are my own.

15 Menachem Elon examined numerous examples of the literary relationship between sources from the Rambam, Tur, and Shulhan Arukh in his Jewish Law, 1327-1341. 
ארבע ציציות מעכבות זו את זו שכל זמן שאין בה

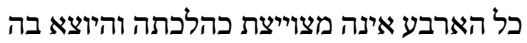

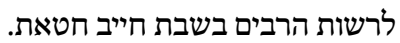

ארבע ציציות מעכבין זה את זה שכל זמן שאין בה כל הארבע אינה מצוייצת כהלכתה והיוצא בה לרשות הרבים בשבת חייב חטאת.

Shulhan Arukh, он 3:7

Mishneh Torah, Hilkhot Beit ha-Behirah

$7: 9$

Whoever urinates from Mt. Scopus inward to the city should sit facing the Temple or have the Temple at his side.
Whoever urinates from Mt. Scopus inward to the city should sit facing the Temple or have the Temple at his side.

Shulhan Arukh, ö 13:1

Tur, ợ 13

The four tzitzit (ritual fringes) can disqualify one another so that as long as all of the four corners do not have tzitzit attached according to the halakhah if one goes out into the public domain on Shabbat they are obligated to bring a sin offering.
The four $t z i t z i t$ (ritual fringes) can disqualify one another so that as long as all of the four corners do not have tzitzit attached according to the halakhah if one goes out into the public domain on Shabbat they are obligated to bring a sin offering.

As can be seen from these sources, there are instances when Karo simply quotes verbatim in the Shulhan Arukh a source from either the Mishneh Torah or the Tur. 


\section{Modification of Source in the Shulhan Arukh}

Already in the very first se'if of the Shulhan Arukh we see an example of how Karo edited a source from the Tur before it was brought in the Shulhan Arukh.

\begin{tabular}{|c|c|}
\hline טוזר אורח חיים סימן א & שלתן ערוך אורה היים א:א \\
\hline לכן צריך האדם להתגבר כארי לעמוד בבקר & יתגבר כארי לעמוד בבקר לעבודת בוראו \\
\hline לעבודת בוראו & שיהא הוא מעורר השחר. \\
\hline \multicolumn{2}{|l|}{ ואף אם ישיאנו יצרו בחורף לאמר איך תעמוד } \\
\hline \multicolumn{2}{|l|}{ בבקר כי הקור גדול או ישיאנו בקיץ לאמר איך } \\
\hline \multicolumn{2}{|l|}{ תעמוד ממטתך ועדיין לא שבעת משנתך התגבר } \\
\hline \multicolumn{2}{|l|}{ עליו לקום, שתהא אתה מעורר השחר ולא יהא } \\
\hline \multicolumn{2}{|l|}{ הוא מעירך כמו שאמר דוד עליו השלום עורה } \\
\hline \multicolumn{2}{|l|}{ כבודי עורה הנבל וכנור אעירה שחר } \\
\hline אני מעיר השחר ואין השחר מעיר אותי. & \\
\hline
\end{tabular}

Shulhan Arukh, oH 1:1

One should gather strength in the morning to arise and worship his creator that he should wake the dawn.
Tur, ọ̈ 1

Therefore a person needs to gather strength in the morning to arise and worship his creator that he should wake the dawn.

And even if in the winter his urge should entice him and say "how can you get up in this great cold," or in the summer it will entice him and "how can you get up from your bed while you still haven't satisfied your sleep?"

Overcome it and get up, that you should wake the dawn and not he wake you as David may he rest in peace said "Awake 
up, my glory; awake, psaltery and harp: I myself will awake early." (Psalms 57:8) I wake up the dawn, and the dawn does not wake me.

In this example Karo selectively chose portions from a larger text that was in the Tur. Other times the editing was as simple as adding a word or a slight modification in order to make a statement easier to understand.

טור אורח חיים שימן א

שלחן ערוך אירח חיים א:ד

טוב מעט תחנונים בכוונה מהרבות בלא כונה. כי טוב מעט בכונה מהרבות בהם שלא בכונה.

\section{Shulhan Arukh, ö 1:4}

Tur, ọ̈ 1

It is better a few supplications with For it is better a few with intention than proper intention than many without many without intention. intention.

טור אורח חיים סימן ד

שלהון ערוך אורח היים ד:כב

ואם אין לו מים יקנח ידיו בצרור או בכל מידי דמנקי ויברך על נקיות ידיים.
אם אין לו מים יקנח ידיו בצרור או בעפר או בכל מידי דמנקי ויברך על נקיות ידיים.

\section{Shulhan Arukh, oH 4:22}

If one does not have water he should clean his hands with a stone or dirt or

\section{Tur, OH 4}

If one does not have water he should clean his hands with a stone or with any- 
(cont.)

Shulhan Arukh, ö 4:22

with anything else that cleans and bless

"on the cleanliness of hands."
Tur, $\mathrm{OH} 4$

thing else that cleans and bless "on the

cleanliness of hands."

In another place Karo made a change that on the surface reflects a different opinion regarding how to write God's name, but on a deeper level may possibly be a different understanding of God based upon the Zohar. ${ }^{16}$

\begin{tabular}{rr}
\hline ליכון ערוּ אזרח חיים ח:ה \\
\hline
\end{tabular}

Shulhan Arukh, ợ 8:8

One should intend in their wrapping [of the tallit] that the Blessed be He commanded us to wrap ourselves in order that we remember all of his commandments and to perform them.

\section{Tur, oH 8}

One should intend in their wrapping [of the tallit] that the Place commanded us to wrap ourselves in it in order that we remember all of his commandments and to perform them.

Other times there is both a slight change in language along with the editing out of a clause.

16 The use of הב"ה in the Venice 1567 edition is most likely an abbreviation for הקברוך, the Holy One Blessed be He, which is either הקודשא בריך הוא or הקדוש ברוך הוא , הקו and it was subsequently changed to הקב"ה in later editions. The influence of the Zohar on Karo will be discussed below. On the different ways in which God's name was written see Yaakov Spiegel, Amudim be-Toldot ha-Sefer ha-Ivri: Ketivah ve-Ha'atakah (Ramat Gan: Bar-Ilan University Press, 2005), 565-632, esp. 592-594. See also Ephraim E. Urbach, The Sages, trans. I. Abrahams (Cambridge: Harvard University Press, 1987), 66-79. 
ולא ישתין מעומד שלא יתזו נצוצות על רגליו ויראה ככרות שפכה ונמצא מוציא לעז על בניו אם לא שיעמוד במקום גבוה או שישתין לתוך

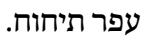

לא ישתין מעומד מפני ניצוצות הניתזין על רגליו אם לא שיעמוד במקום גבוה או שישתין לתוך

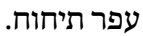

\section{Shulhan Arukh, он 3:13}

A person should not urinate standing up because of the droplets that are sprayed on his legs, unless he stands in a high place or urinates into soft dirt.

\section{Tur, ọ̈ 3}

And a person should not urinate standing up in order that droplets should not spray on his legs and it should not seem as if he is a castrated person and thus causing his sons to be slandered, unless he stands in a high place or urinates into soft dirt.

There are other times when Karo added an interpretation to an otherwise almost verbatim quotation from the Tur.

טור אורח חיים יא

שלהן ערוך אהרח היים יא:ח

המשתחוה לבהמה צמרה פסול לציצית אבל המשתחוה לפשתן נטוע כשר לציצית.
המשתחוה לבהמה צמרה פסול לציצית

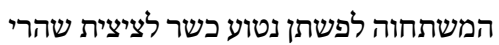

נשתנה. - - - - - - - -

\section{Shulhan Arukh, оب 11:8}

One who bows down to an animal [in order to worship it], its wool is disqualified for tzitzit. One who bows down to planted flax, it is fit for tzitzit since it has changed.

\section{Tur, oH 11}

One who bows down to an animal [in order to worship it], its wool is disqualified for tzitzit, but one who bows down to planted flax, it is fit for tzitzit. 
In this last example Karo added a reason to a law from the Tur that previously did not include one. From the above examples we see that while there were instances in which Karo quoted sources from either the Tur or the Rambam verbatim, there were also examples in which he made changes, some slight and others not so slight, to earlier sources.

\section{The Centrality of the Beit Yosef in the Writing of the Shulhan Arukh}

In this section I will bring examples of different ways in which the Beit Yosef served as a vehicle and a source for later formulations found in the Shulhan Arukh. The first example that I will bring in order to show the important role that the Beit Yosef played in the writing of the Shulhan Arukh will be from the se'if that was brought at the end of the last section, $O H$ 11:8. Above I emphasized how the formulation of this se'if differed in the Shulhan Arukh from the Tur on which it is based and now I will show the role of the Beit Yosef in this modification.

\begin{tabular}{|c|c|}
\hline טור אורח חיים יא & שלהן ערוך אורח חיים יא:ח \\
\hline המשתחוה לבהמה צמרה פסול לציצית & המשתחוה לבהמה צמרה פסול לציצית \\
\hline אבל המשתחוה לפשתן נטוע כשר לציצית. & המשתחוה לפשתן נטוע כשר לציצית שהרי \\
\hline
\end{tabular}

\section{Shulḥan Arukh, оң 11:8}

Tur, он 11

One who bows down to an animal [in order to worship it], its wool is disqualified for tzitzit. One who bows down to planted flax, it is fit for tzitzit since it has changed.
One who bows down to an animal [in order to worship it], its wool is disqualified for tzitzit, but one who bows down to planted flax, it is fit for tzitzit.

As seen in the above quoted se'if, there is a slight change between the Shulhan Arukh and the Tur. In the Beit Yosef Karo directly references the Rambam who included a reason for this specific halakhah and this explanation was then included in the Shulhan Arukh even though it was not found in the Tur. 


\begin{tabular}{|c|c|c|}
\hline רמב"ם הלכות צייצית א:"א & בית יוסף אורח חיים סימן יא & שלהן ערוך אורח חיים יא:ח \\
\hline שסול לציצית אבל המשתוה לבהמה צמרה נשתחוה & 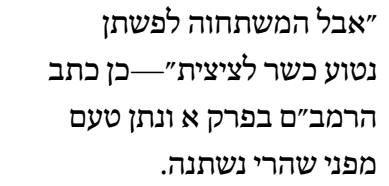 & המשתחוה לבהמה צמרה פסול \\
\hline Shulhan Arukh, оң 11:8 & Beit Yosef, он 11 & $\begin{array}{l}\text { Rambam, Hilkhot Tzitzit } \\
\text { 1:11 }\end{array}$ \\
\hline $\begin{array}{l}\text { One who bows down to } \\
\text { an animal [in order to } \\
\text { worship it], its wool is dis- } \\
\text { qualified for tzitzit. One } \\
\text { who bows down to planted } \\
\text { flax, it is fit for tzitzit since } \\
\text { it has changed. }\end{array}$ & $\begin{array}{l}\text { "But one who bows down } \\
\text { to planted flax, it is fit for } \\
\text { tzitzit": So wrote the Ram- } \\
\text { bam in chapter one [of } \\
\text { the laws of } \text { tzitzit] and } \\
\text { gave a reason, since it has } \\
\text { changed. }\end{array}$ & $\begin{array}{l}\text { If, however, one bows } \\
\text { down to flax which is } \\
\text { planted, it is acceptable, } \\
\text { since it has changed. }\end{array}$ \\
\hline
\end{tabular}

Isadore Twersky has previously written about the instances when Karo seemed to have gone out of his way and removed a reason found in the Rambam for a commandment, yet here we see a case in which Karo went out of his way to include a reason for a commandment that was included by the Rambam but excluded from the Tur. ${ }^{17}$ Another example of when Karo added a reason for a commandment or practice that was not found in the Tur but was brought in the Beit Yosef can be seen in the following source.

In $O H$ 3:11 Karo brings numerous instructions regarding how to clean oneself after defecating. ${ }^{18}$

\footnotetext{
17 See Twersky, "Ha-Rav R' Yosef Karo Ba'al ha-Sh"Ar," Asufot: Sefer Shanah le-Mada'ei haYahadut 3 (1989-1990): 257. As Twersky has shown, Karo's use of sources found in the Rambam was multi-faceted and not uniform.

18 See Julius Press, Biblical and Talmudic Medicine, trans. F. Rosner (New York: Sanhedrin Press, 1978), 55o. Also see this comment by Philippe Charlier et al., "Toilet Hygiene in the Classical Era," British Medical Journal 2012; 345:e8287: "The abrasive characteristics of ceramic suggest that long term use of pessoi [i.e. pebbles, MP] could have resulted in local irritation, skin or mucosal damage, or complications of external haemorrhoids."
} 


\begin{tabular}{|c|c|c|}
\hline בית יוסף אורח היים סימן ג & טוזר אזרח חיים סימן ג & שלחן ערוך אורח היים ג:יא \\
\hline "ולא יקנח בחרס משום & ולא יקנח בחרס משום כשפים & לא יקנח בחרס משום כשפים \\
\hline כשפים"-_סוף פרק המוציא & ולא בעשבים יבשים & ולא בעשבים יבשים שהמקנח \\
\hline (שבת פב ע"א) ובפרק (חולין & ולא בצרור שקינח בו חברו. & בדבר שהאור שולט בו שיניו \\
\hline קה ע"ב) & & התחתונות נושרות. \\
\hline "ולא בעשבים יבשים"-_-גם זה & & ולא בצרור שקינח בו חבירו \\
\hline בסוף פרק המוציא (שבת פב & & מפני שמביא את האדם לידי \\
\hline ע"א) וטעמא משום דהמקנח & & תחתוניות. \\
\hline \multicolumn{3}{|l|}{ בדבר שהאור שולטת בו שיניו } \\
\hline \multicolumn{3}{|l|}{ התחתונות נושרות ... } \\
\hline \multicolumn{3}{|l|}{ "ולא בצרור שקנח בו חבירו"-_ } \\
\hline \multicolumn{3}{|l|}{ בסוף פרק הרואה (ברכות נה } \\
\hline \multicolumn{3}{|l|}{ ע"א) עשרה דברים מביאים את } \\
\hline \multicolumn{3}{|l|}{ האדם לידי תחתוניות ואחד מהן } \\
\hline המקנח בצרור שקינח בו חבירו. & & \\
\hline
\end{tabular}

Shulhan Arukh, о ب̣ 3:11

A person should not wipe themselves with a pottery shard because of witchcraft nor with dried grass, since one who wipes themselves with something that is affected by light his bottom teeth fall out. Nor with a rock that his friend used to wipe himself since it causes a person to develop hemorrhoids.

\section{Tur, ợ 3}

A person should not wipe themselves with a pottery shard because of witchcraft nor with dried grass nor with a rock that his friend used to wipe himself. himself.

\section{Beit Yosef, он 3}

"A person should not wipe themselves with a pottery shard because of witchcraft"-At the end of chapter "ha-motzi" (b. Šabb. 82a) and in chapter "kol ha-basar" (b. Hul. 105b). "Nor with dried grass"-This is also at the end of chapter "ha-motzi" (b. Šabb. 82a). And the reason is that since one who wipes themselves with something that is affected by light his bottom teeth fall out. "Nor with a rock that his friend used to wipe himself" - At the end of 


\begin{tabular}{|c|c|c|}
\hline \multirow[t]{7}{*}{ Shulhan Arukh, о ㅂ 3:11 } & Tur, он 3 & Beit Yosef, он 3 \\
\hline & & the chapter "ha-ro'eh" (b. \\
\hline & & Ber. $55^{a}$ ): "ten things cause \\
\hline & & a person to develop hem- \\
\hline & & orrhoids and one of them \\
\hline & & is wiping with a rock that \\
\hline & & his friend used." \\
\hline
\end{tabular}

In this se'if we see how in the Shulhan Arukh Karo quoted the Tur verbatim yet also felt the need to add comments that explained the halakhah. Unlike the case cited above where Karo added an explanation that was found in the Rambam, ${ }^{19}$ here Karo added two explanations that were based on the Talmud and were brought in the Beit Yosef.

In some instances Karo codified a halakhah in the Shulhan Arukh that is not found in the Tur. $O H 13$ discusses which types of four-cornered garments are obligated to have tzitzit on them, specifically the difficult cases when the garments are not entirely open at the sides, but rather only partially open. How much does the garment have to be open at the sides in order for it to be required to have tzitzit? The Tur addressed a number of related issues, but there was enough missing that Karo brought a large amount of supplementary material in his Beit Yosef, and some of this was later incorporated into the Shulhan Arukh.

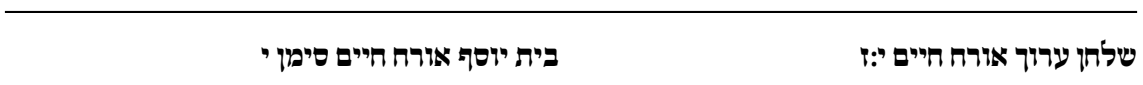

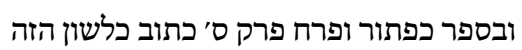

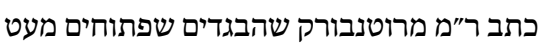

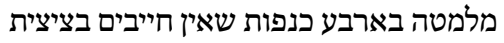

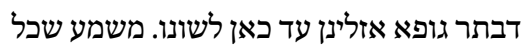
שאין רובו סתום בגד ארבע כנפות מיקרי וחייב

בציצית ולא פטר הר״מ אלא כשרובו סתום ... וכן כתב מהרי"ק בשורש קמ"ט דלא פטר רבינו שמחה אלא דווקא בשרובה סתום אבל אם רובה פתוח חייבת ....

מלבושים שהם פתוחים מן הצדדין למטה ויש

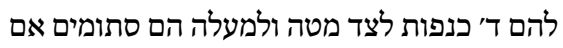

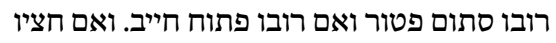
סתום וחציו פתוח מטילין אותו לחומרא וחייב

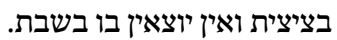

19 That Rambam does not codify any of the halakhot found in this se'if in his Mishneh Torah. For related material see chapters four and five of Hilkhot De'ot.
} 
(cont.)

בית יוסף אורח חיים סימן י

שלתו ערוך אירה חיים י:ף

ובהכי הרשב"א ורבינו שמחה מסכימים לדעת

אחת ואם חצי הבגד סתום וחציו פתוח נראה לי לי

דמטילין אותו לחומרא וחייב בציצית ואין יוצאין

בו בשבת ...

Shulhan Arukh, ọ̈ 10:7

Articles of clothing that are open on the sides at the bottom and they have four corners at the bottom and at the top they are closed, if the majority of it is closed it is exempt [from tzitzit] and if the most of it is open it is obligated. If half of it is closed and half is open one attaches [tzitzit] in order to be strict and it is obligated to have tzitzit and one does not go out with it [into the public domain] on Shabbat.
Beit Yosef, он 10

In the book Kaftor va-Ferah chapter 60 it is written in the following language: Rabbi Meir of Rothenberg wrote that articles of clothing that are open a little bit at the bottom of the four corners are not obligated to have $t z i t z i t$ since we follow the body [of the garment]. It seems that anything that is mostly open is considered a four-cornered garment and is obligated in tzitzit. Rabbi Meir only exempted [a garment] which was mostly open ... so too wrote the Maharik in section 149, that Rabbeinu Simchah did not exempt a garment except one that was mostly closed but if most of it was open it was obligated [to have tzitzit] ... And in this case the Rashba and Rabbeinu Simchah agreed. and if half of the garment is closed and half is open, it seems to me that we attach tzitzit in order to be strict and it is obligated in tzitzit and one does not go out with it [into the public domain] on Shabbat. 
In the Beit Yosef on $O{ }_{1}$ 13, Karo brought many medieval sources that addressed these partially opened four-cornered garments. These sources included responsa collections such as the responsa of the Rashba ${ }^{20}$ and the Maharik ${ }^{21}$ in addition to codes such as Kaftorva-Ferah.

In the Beit Yosef Karo quoted some of these sources verbatim while others he paraphrased. Similarly, in the Shulhan Arukh Karo quoted some of his statements from the Beit Yosef verbatim while he also paraphrased and reformulated other material. This se'if in the Shulhan Arukh shows how sometimes the Beit Yosef was used as a supplementary commentary on the Tur, addressing material and issues that were not directly addressed in the Tur. This material was then subsequently brought in the Shulhan Arukh, sometimes verbatim while at other time paraphrased and modified.

\section{The Beit Yosef and the Influence of the Zohar on the Shulhan Arukh}

I would now like to address a specific phenomenon found in the relationship between the Beit Yosef and the Shulhan Arukh. $O H 4$ discusses the laws surrounding netilat yadayim, washing one's hands in the morning and before prayer. When one compares the amount of material found in this siman in the Tur and the Shulhan Arukh it isn't hard to see that the Shulhan Arukh contains much more material on this subject than does the Tur. The material in the Tur amounts to just a few lines. ${ }^{22}$

One should wash their hands hygienically and bless "Blessed are You Lord our God who has commanded us on washing hands."

One should be meticulous to pour over them three times since an evil spirit dwells on the hands until they are washed and is not removed until one pours water on them three times. There-
וירחץ בנקיון כפיו ויברך ברוך אתה י"י אלהינו

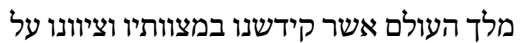

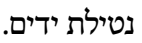

וידקדק לערות עליהם שלושה פעמים מפני שרוח

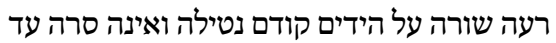
שיערה עליהם שלוש פעמים ועל כן צריך למנוע מהגיע בידו קודם נטילה לפה ולחוטם ולאיה פעים ועלוזניים ולעיניים מפני שרוח רעה שורה עליהם.

\footnotetext{
$20 \quad$ R. Shlomo ben Aderet.

21 R. Yosef Colon.

22 On the concept of רוח רעה see 1Sam 16:14, 23; m. Šabb. 2:5; b. Pesah. 112a.
} 
(cont.)

Tur, ọ̈ 4

טור, אירח חיים סימן ד

fore one needs to refrain from touching his mouth, nostrils, ears, and eyes, with his hands before washing because an evil spirit is dwelling on them.

And if one does not have water he should clean his hands with a rock or anything

ואם אין לו מים יקנח ידיו בצרור או בכל מיני דמנקי ויברך" על נקיות ידיים". else that cleans and bless "on the cleanliness of hands."

The subjects addressed in this siman are the following: 1. The blessing recited when washing one's hands in the morning; 2 . How many times water is poured over the hands and how; 3. What happens when a person does not have water.

Unlike this relatively small amount of material in the Tur, the Shulhan Arukh contains a total of 23 se'ifim on this topic. A closer examination of the differences between them shows how in the Shulhan Arukh Karo added a large amount of material to what is found in the Tur. Primarily, although not exclusively, this material came from the Zohar.

The first example will be regarding the possible relationship between washing one's hands in the morning and washing one's hands before eating a meal. In siman 4 of the Tur there is no mention at all of washing one's hands before eating a meal while in the Shulhan Arukh the relationship is explicitly addressed. The Shulhan Arukh contains the following in 4:7.

It is good to be meticulous about washing one's hands in the morning regarding anything that disqualifies washing one's hands for a meal.
טוב להקפיד בנטילת ידיים שחרית בכל הדברים המעכבים בנטילת ידיים לסעודה.

An examination of the Beit Yosef on this siman shows Karo's sources for making the connection between washing one's hands in the morning and washing one's hands before eating a meal. 
And it seems from the words of the Rosh that we do not need a vessel for washing hands in the morning as one requires for washing hands for a meal. And so it is written in Hagahot Mordechai chapter "Eilu Devarim," and so wrote the Ran in the beginning of chapter "Kol haBasar." It seems that so too is the law regarding other things that disqualify washing hands for a meal that they are not required for washing hands in the morning since this washing is only for the purpose of cleanliness.

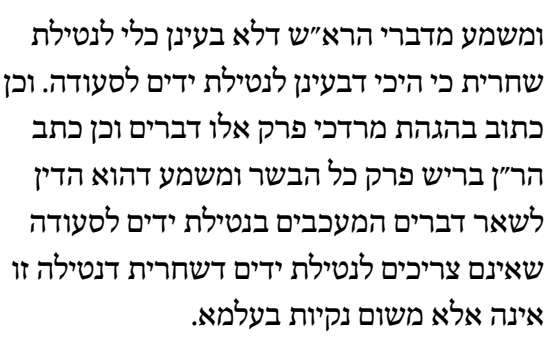

ומשמע מדברי הרא"ש דלא בעינן כלי לנטילת

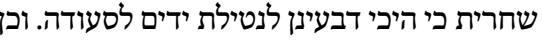
כתוב בהגהת מרדכי פרק אלו דברים וכן כתב הר"ן בריש פרק כל הבשר ומשמע דהוא הדין לשאר דברים המעכבים בנטילת ידים לסעודה אינה אלא משום נקיות בעלמא.

The sources quoted here by Karo in the Beit Yosef seem to imply that there isn't any connection between the laws of washing one's hands in the morning and those of washing one's hands before eating a meal, so why then did he write in the Shulhan Arukh that it is "טוב להקפיד בנטילת ידיים שחרית בכל הדברים המעכבים בנטילת ידיים לסעודה relating to washing one's hands in the morning just as one would regarding washing one's hands before a meal"?

If one wants to focus on the narrow literary source for Karo's formulation in 4:7, the source seems to be a based upon a statement in the Beit Yosef, specifically a responsum of the Rashba. ${ }^{23}$

\begin{tabular}{|c|c|}
\hline בית יוסף אורח היים סימן ד & שלהן ערוך אורח היים ד:ז \\
\hline ומשמע דהוא הדין לשאר דברים המעכבים & טוב להקפיד בנטילת ידיים שחרית בכל הדברים \\
\hline בנטילת ידים לסעודה שאינם צריכים לנטילת & המעכבים בנטילת ידיים לסעודה \\
\hline \multicolumn{2}{|l|}{ ידים דשחרית דנטילה זו אינה אלא משום נקיות } \\
\hline \multicolumn{2}{|l|}{ בעלמא. } \\
\hline אבל בתשובת הרשב"א כתוב שנשאל למה תקנו & \\
\hline ברכת על נטילת ידים בשחרית והשיב איברא כך & \\
\hline
\end{tabular}

23 See Responsa of the Rashba I:191. 
(cont.)

בית יוסף אורח חיים סימן ד

שלחן ערוך אירח היים ד:ז

נהגו בכל מקום לברך בשחרית על נטילת ידים

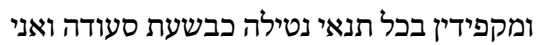

לא מצאתי בשום מקום דבר ברור שיצטרך אדם

ליטול ידיו שחרית .... לאי בשום מקום

\section{Shulhan Arukh, оب̣ 4:7}

It is good for one to be meticulous in washing one's hands in the morning regarding all things that disqualify washing one's hands for a meal.

\section{Beit Yosef, он 4}

And we learn that the same laws that apply to the other things that disqualify washing one's hands for a meal do not apply to washing one's hands in the morning since this hand washing is only because of cleanliness.

But in a responsum of the Rashba it is written that he was asked why the blessing "on washing hands" was established for [washing hands] in the morning and he responded: It is clear that this is the practice everywhere, to bless in the morning "on washing hands," and they are meticulous about all of the conditions that apply to the washing just as like with a meal.

And I didn't find any clear source that would require a person to wash their hands in the morning.

It still needs to be explained why Karo moved from his first statement where he said that it seemed there was no necessary correlation between the laws of washing one's hands in the morning and those of washing one's hands before eating a meal to the recommendation that one should be meticulous in matters relating to washing one's hands in the morning just as one would regarding washing one's hands before a meal. 
After bringing a number of halakhic authorities, some of whom supported such a correlation and some who opposed, Karo proceeded to bring a number of sources from the Zohar, "וכן כתוב בספר הזוהר". In this instance the sources from the Zohar played the role of tilting the scales in favor of one school of halahkic thought over another.

This decision by Karo to attribute to the Zohar a central role in the discussion of this topic can be seen in most of the seifim in this siman. See for example the following. ${ }^{24}$

נוטל כלי של מים ביד ימינו ונותנו ליד שמאלו כדי ואפשר שיש חילוק בין נטילת ידים דשחרית

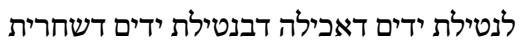
שיריק מים על ימינו תחילה. כיוון שהם טמאות מסטרא מסאבא דשרייא

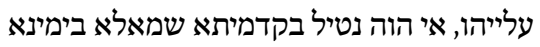

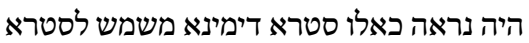

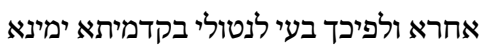
משמאלא כמו שכתוב בפרשת וישב.

אבל בנטילת ידים לאכילה שידיו הם טהורות

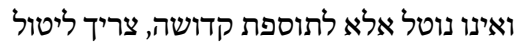
תחילה יד שמאל מיד ימין מהטעם שכתב

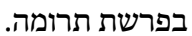

ויש לפרש שלעולם תחילה נוטל יד ימין מיד שמאל, בין בנטילת ידים דשחרית בין ביל בנטלי ימילת

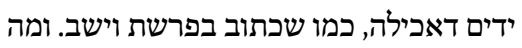

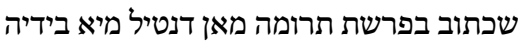

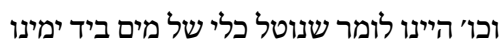
ונותנו ליד שמאלו כדי שיריק מים על יד ימינו

24 In order to understand this se'if it is important to note that according the Zohar the left side, sitra de-smola, is considered evil. See Joseph Dan, Kabbalah: A Very Short Introduction (Oxford: Oxford University Press, 2006), 52-53: "In the Zohar the realm of evil is called sitra ahra, an Aramaic phrase meaning 'the other side.' 'Other' is the unmentionable left side, which is also the name of God's archenemy, Samael." 
Shulhan Arukh, оң 4:10

One takes a vessel of water in his right hand and passes it to his left [hand] in order that he pour out the water on his right hand first.

\section{Beit Yosef, оң 4}

And it is possible that there is a difference between washing hands in the morning and washing hands for eating since in the case of washing hands in the morning, because [the hands] are impure on account of the impure side that is resting on them, if he would first have water poured from right hand onto his left hand it would seem that the right power ("sitra de-yemina") is working for the other side ("sitra ahra"), therefore one needs to first pour on his right hand from his left hand as it is written in Parashat Vayeshev [in the Zohar].

But in the case of washing hands for a meal when one's hands are pure and washing is only done in order to add holiness, one needs to first pour from the right hand on the left hand as is written in Parashat Terumah [in the Zohar]. One should interpret that first the right hand is always washed from the left hand, whether it is for washing in the morning or for a meal, as it is written in Parashat Vayeshev [in the Zohar]. And that which is written in Parashat Terumah [in the Zohar], "whoever pours water on his hand," that means to say that one takes a vessel of water in his right hand and passes it to his left [hand] in order that he pour out the water on his right hand first. 
In this case Karo addresses the question of in which hand a person first holds the vessel for washing one's hands, the right or the left. When confronted with two possibly conflicting sources from the Zohar, Karo decided that one begins by holding the vessel in the right hand, then passes it to the left hand, and while it is in the left hand, water is then poured over the right hand.

The role of these Zoharic sources in Karo's decision-making process in this siman was directly addressed by Jacob Katz.

Karo, working systematically on the basic of a comprehensive survey of the sources, absorbed Zoharic prescription and granted them higher status than had any halakhist before him. In Chapter 4 of the Beyt Yosef which deals with "hand-washing in the morning," Karo quotes a long passage from the Zohar as supporting evidence before announcing his decision between two conflicting schools of thought. Was the Talmudically prescribed hand-washing in the morning a mere hygenic provision or was it, rather, a ritual one requiring the observance of all minutiae connected with the washing of hands before a proper meal. Karo adopted the second position for which he found support in the Zoharic passage he quoted. ${ }^{25}$

Katz continued and discussed the relationship between Karo's discussion of this topic in the Beit Yosef and his later formulation in the Shulhan Arukh.

While in the Beyt Yosef these prescriptions were wrapped in Zoharic symbolism which they were intended to reflect, in the Shulhan Arukh they were reduced to a few laconic statements. ${ }^{26}$

Katz then added an important observation that helps us understand Karo's thoughts about the role of Zoharic material in the halakhic process in a clearer fashion.

In the first of these concerning the ritual minutiae of hand-washing, where the Zohar had merely supported one of two halakhic opinions

25 Jacob Katz, Divine Law in Human Hands: Case Studies in Halakhic Flexibility (Jerusalem: Magnes Press, 1998), 53. For a discussion on the role of the Kabbalah in Karo's halakhic decision-making process see Moshe Hallamish, Ha-Kabbalah bi-Tefillah, be-Halakhah, uveMinhag (Ramat Gan: Bar-Ilan University Press, 2000), 161-179. 
Karo's decision was presented as a recommendation only. ('It is commendable to take care. ${ }^{27}$ ) The others, based exclusively on the Zohar's authority and uncontested by any known halakhist, were formulated authoritatively ... For Karo ... the Zoharic view would be binding as long as it was not explicitly repudiated in the Talmud. ${ }^{28}$

This siman illustrates another aspect of the Shulhan Arukh in relation to earlier sources and that is the importance of Zoharic sources for Karo in his formulation of halakhic practice. In this case Karo first discussed these sources and opinions in the Beit Yosef and it is possible to see how they then migrated to the Shulhan Arukh.

\section{$O \underset{1}{ } 17$ As an Example of Different Editorial Actions by Yosef Karo within the Same Siman}

If we look at $O H 17$, we can see how within one relatively short chapter Karo quoted and added to the foundation that he found in the Tur with material from the Beit Yosef, chose to edit a larger selection from the Tur while at the same time adding new material, and then chose to quote from the Tur verbatim without adding anything. The first se'if is an example of Karo quoting from the Tur but adding additional material to this quotation.

\begin{tabular}{|c|c|c|}
\hline בית יוסף אורח חיים סימן יז & טור אורח חיים סימן יז & שלחו ערוך אורח חיים ייז:א \\
\hline דתניא וראיתם אותו פרט & סומא חייב בציצית. & אף על גב דכתיב וראיתם \\
\hline לכסות לילה אתה אומר פרט & & אותו סומא חייב בציצית מפני \\
\hline לכסות לילה או אינו אלא פרט & & שנתרבה מאשר תכסה בה \\
\hline לכסות סומא כשהוא אומר & & וקרא דוראיתם אותו איצטריך \\
\hline אשר תכסה בה הרי כסות סומא & & למעט כסות לילה. \\
\hline אמור. & & \\
\hline
\end{tabular}

27 In 4:7, טוב להקפיד.

28 Ibid. 


\begin{tabular}{|c|c|c|}
\hline Shulhan Arukh, ö 17:1 & Tur, оH 17 & Beit Yosef, он 17 \\
\hline $\begin{array}{l}\text { Even though it is written } \\
\text { "and you shall see it" (Num } \\
\text { 15:39) a blind person is } \\
\text { obligated in tzitzit because } \\
\text { it was included in the } \\
\text { interpretation of "which } \\
\text { you shall cover with" (Deut } \\
22: 12 \text { ), and the verse "and } \\
\text { you shall see it" is needed } \\
\text { in order to exclude [from } \\
\text { the commandment] night- } \\
\text { time garments. }\end{array}$ & $\begin{array}{l}\text { A blind person is obligated } \\
\text { in tzitzit. }\end{array}$ & $\begin{array}{l}\text { It is taught in a baraita: } \\
\text { "and you shall see it" (Num } \\
\text { 15:39)_excluding night- } \\
\text { time garments. You say } \\
\text { that it excludes nighttime } \\
\text { garments, but maybe it } \\
\text { excludes the garments } \\
\text { of a blind person? When } \\
\text { he says "which you shall } \\
\text { cover with" (Deut 22:12) it } \\
\text { is speaking about the gar- } \\
\text { ments of a blind person. }\end{array}$ \\
\hline
\end{tabular}

Karo's comments in the Beit Yosef on this siman seem to be the source for the contextualization of the quotation from the Tur. Here Karo does not quote his own words from the Beit Yosef verbatim, he rather summarizes the conclusions of the baraita that he brought in the Beit Yosef and in the Shulhan Arukh wrote his own reformulation of that source. ${ }^{29}$

In the next se'if we see another example of when Karo copies certain parts from the Tur but at the same time adds to the material from the Tur.

\begin{tabular}{|c|c|}
\hline טוּר אזרח חיים סימן "י & שלחת ערוך אורח חיים ייז:ב \\
\hline ונשים ועבדים פטורים. & נשים ועבדים פטורים מפני שהיא מצות עשה \\
\hline וטומטום ואנדרוגינוס חייבין מספק. וכתב & שהזמן גרמא טומטום ואדרוגינוס חייבין מספק \\
\hline הרמב"ם ז״ל יתעטפו בלא ברכה והוא הולך & ויתעטפו בלא ברכה. \\
\hline \multicolumn{2}{|l|}{ לשיטתו שפירש שנשים אין יכולות לברך בדבר } \\
\hline \multicolumn{2}{|l|}{ שהן פטורות. אבל רבינו תם כתב שיכולות לברך } \\
\hline אף על פי שהן פטורות ויותר טוב שלא יברכו. & \\
\hline
\end{tabular}

29 The baraita is found on b. Menah. 43a. 


\section{Shulhan Arukh, он 17:2}

Women and slaves are exempt [from tzitzit] since it is a positive time-bound commandment. A tumtum and androgynos are obligated because of a doubt [whether they are obligated or not] and they should wrap themselves [in a fourcornered garment with $t z i t z i t]$ without reciting a blessing.

\section{Tur, $\mathrm{OH} 17$}

And women and slaves are exempt [from tzitzit] and tumtum and androgynos are obligated because of a doubt [whether they are obligated or not]. And the Rambam wrote: they should wrap themselves [in a four-cornered garment with $t z i t z i t$ ] without reciting a blessing. He follows his own approach since he interpreted that women are unable to make a blessing on something from which they are exempt, but Rabbeinu Tam wrote that they are able to make a blessing even if they are exempt. It's best if they don't bless.

The additional material found in this se'if again seems to be from a baraita that is brought in the Beit Yosef.

\section{Beit Yosef, ơ 17}

בית יוסף אורח חיים סימן יז"

In the chapter "techeilet" (b. Menah. 43a) our rabbis taught: Everyone is obligated in tzitzit, Priests, Levites, Israelites, converts, women, and slaves. R. Shimon exempts women since it is a positive time-bound commandment and women are exempt from all positive time-bound commandments.
בפרק התכלת תנו רבנן הכל חייבים בציצית,

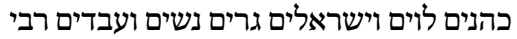
שמעון פוטר בנשים מפני שמצות עשה שהזמן

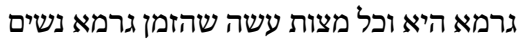

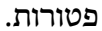

In this case it was the Tur who did not see fit to include any explanation why women and slaves are exempt from the mitzvah of tzitzit, even though this reason is found in the Talmud. Karo then chose to return the explanation to his discussion of the exemption, adding it between two different quotations from the Tur. 
The last se'if in this siman is an example of a verbatim quote from the Tur that explains that relationship of a minor to the mitzvah of $t z i t z i t$.

\begin{tabular}{|c|c|}
\hline טור אורח היים סימן יז & שלחן ערוך אורח היים יז:ג \\
\hline קטן היודע להתעטף אביו צריך ליקח לו ציצית & קטן היודע להתעטף אביו צריך ליקח לו ציצית \\
\hline לחנכו. & 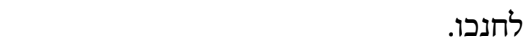 \\
\hline
\end{tabular}

Shulhan Arukh, он̣ 17:3

Tur, оң 17

A minor who knows how to wrap himself

A minor who knows how to wrap himself in a four-cornered garment with tzitzit, in a four-cornered garment with tzitzit, his father needs to take for him tzitzit in order to educate him. his father needs to take for him tzitzit in order to educate him.

It should also be emphasized that the order of the halakhot in this siman are identical to those found in the Tur.

1. Obligation of a blind person with regard to the mitzvah of tzitzit.

2. Obligation of women and slaves with regard to the mitzvah of tzitzit.

3. Obligation of tumtum and androgenus with regard to the mitzvah of tzitzit and whether they recite a blessing.

4. Performance of the mitzvah of tzitzit by a minor.

From the examination of this single siman that includes only three se'ifim we can see how Karo chose a different approach to the formulation of every se'if and seif, even within the same siman, while at the same time relying upon the overall structure of the siman found in the Tur.

\section{Conclusion}

Menachem Elon summarized the literary methodology of the Shulhan Arukh in the following words.

The method of the Shulhan Arukh is distinct from that of the other codes. The Shulhan Arukh states the substance of the law briefly, sometimes adopting the formulation of the Turim for this purpose. However, when 
clarity is particularly needed, the Shulhan Arukh frequently prefers Maimonides' text; and in these instances, the Shulhan Arukh is more expansive than the Turim. The Shulhan Arukh presents only the normative rule; in contrast to Maimonides and the Turim, it includes neither rationales for the law nor any philosophic considerations. Laws are generally stated without attribution of source and with no reference to contrary opinions. ${ }^{30}$

There is much in common with my conclusions after examining the first 25 simanim of the Shulhan Arukh and those of Elon. The literary foundations of the Shulhan Arukh can be found in the Rambam, the Tur, and the Beit Yosef. When Karo chose to deviate from a verbatum quotation from either the Rambam or the Tur the reasons varied, sometimes it was in order to clarify a difficult to understand statement, while other times it reflected legal or theological considerations. In addition, Karo's Beit Yosef served as a conduit for sources that he felt were needed to supplement what was found in the Rambam and the Tur.

Far from being a mere collection of sources, Karo's Shulhan Arukh represents a new literary creation, one that while standing on the shoulders of both his own work and that of others, is also a new and creative restatement of Jewish law.

\section{Bibliography}

Charlier Philippe, et al. "Toilet Hygiene in the Classical Era." British MedicalJournal 2o12, $345: \mathrm{e} 8287$.

Dan, Joseph. Kabbalah: A Very Short Introduction. Oxford: Oxford University Press, 2006.

Elon, Menachem. Jewish Law: History, Sources, Principles. Translated by B. Auerbach and M. Sykes. Philadelphia: Jewish Publication Society, 1994.

Gray, Alyssa. "Poverty and Community in R. Joseph Karo's Shulhan Arukh: 'Law and Literature' and Halakhic History." Diné Israel 29 (2013): 57*-89*.

Hallamish, Moshe. Ha-Kabbalah bi-Tefillah, be-Halakhah, uve-Minhag. Ramat Gan:BarIlan University Press, 2000.

Kahana, Yitzhak Ze'ev. Mehkarim be-Sifrut ha-Teshuvot.Jerusalem: Mossad Harav Kook, 1973.

$30 \quad$ Elon, 1339 . 
Katz, Jacob. Divine Law in Human Hands: Case Studies in Halakhic Flexibility. Jerusalem: Magnes, 1998.

Kelman, Tirza. "Ketuvot be-Ot Barzel ve-Oferet bi-Defus: Mahapeikhat ha-Defus veYetzirat ha-Hibbur Beit Yosef." Pe'Amim 148 (2016): 9-26.

Lavi, Yehudah. "Otzar ha-Sefarim shel ha-Beit Yosef." Ha-Ma'ayan 34, no. 2 (Tevet 5744): 21-42.

Press, Julius. Biblical and Talmudic Medicine. Translated by F. Rosner. New York: Sanhedrin, 1978.

Shochetman, Eliav. "Al Ha-Setirot be-Shulhan Arukh ve-Al Mahuto Shel Ha-Hibbur UMațarotav." Asufot: Sefer Shanah le-Mada'ei ha-Yahadut 3 (1989-199o): 323-329.

Spiegel, Yaakov. Amudim be-Toldot ha-Sefer ha-Ivri: Ketivah ve-Ha'atakah. Ramat Gan: Bar-Ilan University Press, 2005.

Twersky, Isadore. "Ha-Rav R' Yosef Karo Ba'al ha-Sh"Ar." Asufot: Sefer Shanah le-Mada'ei ha-Yahadut 3 (1989-1990): 245-262.

Urbach, Ephraim E. The Sages. Translated by I. Abrahams. Cambridge: Harvard University Press, 1987.

Yosef, Yitzhak. Ein Yitzhak. Jerusalem: Ei"sh Pituhim, 2009. 